\title{
An investigation into the suitability of younger generation successors in small and medium-sized family businesses
}

\author{
S.P. van der Merwe* \\ Potchefstroom Business School, North-West University \\ Private Bag X6001, Potchefstroom 2520, Republic of South Africa \\ Stephan.vandermerwe@nwu.ac.za
}

Received March 2010

\begin{abstract}
This study highlighted the importance of the suitability of the younger generation family members in small and mediumsized family businesses to successfully manage the business after management succession. Data from 270 questionnaires linked to 77 family businesses were collected and analysed. An Oblimin oblique rotation was performed on the principal components of the exploratory factor analysis. Five factors with eigen-values greater than one, explaining $65,78 \%$ of the variance, were extracted. These five factors describing the theoretical dimensions of the dependent variable, the suitability of the younger generation to manage the family business after succession, and the independent variables, namely value adding by the younger generation, willingness of the younger generation, credibility of the younger generation and the degree of self-empowerment by the younger generation family members. The findings of this study indicated that the three independent variables, value-adding of the younger generation, the willingness of the younger generation to be in the family business and the credibility of the younger generation have a significant positive influence on the perceived suitability of the younger generation. Practical recommendations are suggested to ensure a smooth final transfer of the management and control of the business to the younger generation family members.
\end{abstract}

*To whom all correspondence should be addressed.

\section{Introduction}

Family businesses made an important contribution to wealth creation in the world (Farrington, 2009:64; Venter \& Boshoff, 2005:283; Basu, 2004:13; Morck \& Yeung, 2004:391; Astrachan \& Shanker, 2003:212). Family businesses, however, face the dilemma of long-term survival (Brenes, Madrigal \& Molina-Navarro, 2006:373). Successful succession is critical to the sustainability of the family business. A smooth and effective succession process requires that the younger generation family members gain acceptance, credibility and legitimacy among family members and non-family members. They need to work hard to prove themselves. This process should be negotiated up front with the younger generation as to identify specific skills and competencies that have to be developed to prepare them to successfully manage the family businesses after management succession.

Although widespread attention has been given to the succession issues by family business researchers, succession literature remains noncumulative and disjointed (Le BretonMiller, Miller \& Steier, 2003). During the 2009 International Family Enterprise Research Academy (IFERA) conference, several policy papers (e.g. Berent, Flören, Uhlaner \& Appelman, 2009; Craig \& Moores, 2009) emphasised again that succession is still one of the major research issues and should be addressed by researchers and practitioners alike (Van der Merwe, Venter \& Ellis, 2009:3). There is thus ample justification, against the barren background of scientific value-added research, to pursue more earnest investigations into the unique challenges facing family businesses globally, in general, and specifically in the South African business environment (Van der Merwe et al., 2009:3).

For the purpose of this study, the definition of Ibrahim and Ellis (2004:5) was adopted. They defined a family business as follows: at least 51 percent of the business is owned by a single family; moreover, at least two family members are involved in the management or operational activities in the business; and the transfer of leadership to younger generation family members is anticipated. The South African National Small Business Act (1996) and National Small Business Amendment Act (29/2004:2) classify micro, very small, small and medium-sized businesses as businesses that employ less than a 200 full-time equivalent of paid employees.

This study will thus be targeted at small and medium-sized family businesses in South Africa for two reasons: firstly, the increasingly important role of the small business sector in creating jobs and distributing wealth; and secondly, most family businesses being found in this sector. 


\section{Problem statement}

As family businesses are a primary contributor to economic development and job creation in the world, their general lack of longevity is a cause for concern. The successful transfer of the business to the younger generation family members is important for a healthy and sustainable family business. The younger generation can contribute significantly to the survival of the family business by injecting new energy and vitality. The younger generation family member or prospective successor should, however, be capable and willing to take over the business in the future.

The study aims to expand on the limited information that exists regarding management succession in small and medium-sized businesses by investigating the determinants that impact on the perceived suitability of the younger generation successor to successfully manage the business after management succession.

\section{Objectives of the study}

A capable and willing younger generation family member is important for the successful transfer of the management of the family business. Against this background, the primary objective of this study is twofold: firstly to identify the determinants that could impact on the suitability of the successor to successfully manage the family business after management succession; and secondly to make practical recommendations on actions that families can take to ensure a smooth final transfer of the management of the business to the younger generation family members.

In order to address the primary objective of this study, the following secondary objectives have been formulated:

- To undertake a theoretical investigation into the determinants of the suitability of the younger generation successor to successfully manage the business after transfer;

- To determine the items that could measure those determinants;

- To determine the validity and reliability of the measuring instrument;

- To investigate the relationships between the dependent variable, perceived suitability of the younger generation, and the independent variables identified during the theoretical investigation;

- To investigate the relationship between the variables and selected demographical variables; and

- To put forward recommendations based on the empirical results of this study in order to assist family businesses to ensure the availability of capable and willing younger generation family members to successfully manage the business after management succession.

\section{Operationalisation of variables}

The succession process refers to a series of identifiable steps that take place over time, with the expectation of ensuring the readiness of the younger generation successor to take over the difficult task of leadership when required (Maas, Van der Merwe \& Venter, 2005:54; Ibrahim \& Ellis, 2004:225; Venter, 2003:81). Succession can be defined as a process during which a business is transferred from one generation to the next (Hess, 2006:77; Balshaw, 2003:110). Management succession implies the transfer of management control from the senior generation owner-manager to the next generation successor (Phan, Butler \& Lee, 2005:8). For the purpose of this study, senior generation ownermanagers are those member(s) of the senior or retiring family generation, in most instances the founders of the family business that are the current executive manager of the family business, and have to transfer the family business to the younger generation family members or off-spring.

\section{Dependent variable}

\section{Suitability of the younger generation}

Preparing the younger generation is a life-long process that starts at a very early age and it should not begin when the senior generation owner-manager starts to plan for retirement (Aronoff \& Ward, 1992a:7). This process of introduction should begin even before the younger generation joins the family business (Afghan \& Wiqar, 2007:3). The development of capable successor managers is a critical factor in family business succession (Netsianda, 2008:74; $;$ Daba, 2007:90; Rawls, 1999:179). Schuman (2004:1) emphasised that to improve the change of survival and success across generations, a family business should engage in a deliberate programme of planned, strategic career development.

Succession is driven by a biological clock as the ages of the senior generation owner-managers of the business and their designated successors determine the timing of succession (Daba, 2007:53; Swart, 2005:4). The actual transfer of control to the successor takes place when the founder retires (Netsianda, 2008:44). Having the senior generation ownermanager plan to disengage form the business is necessary, but by itself it is not sufficient to ensure a successful transition. The other ingredient is a competent replacement (Dyer, 1986:126). If a potential successor is not endowed with the necessary skills to take over the management of the business, succession may not take place, because such under-qualification may either lead him or her to refuse the position or cause the dominance coalition to reject the potential successor (De Massis, Chua, \& Chrisman, 2008:186).

Voeller, Fairburn and Thompson (2002:79) recommend that the development of the younger generation starts by determining what kind of leadership (entrepreneurial or managerial) the business needs for the years ahead and then define what specific qualities and skills the type of leader will require. Rawls (1999:180) supports this first step and stated that the core set of skills are similar across various industries. Successor preparation should thus bridge the gap 
between die current competency of the younger generation and the future management and leadership requirements of the family business.

The successor must be able to work independently and provide leadership for the entire organisation (Ibrahim \& Ellis, 2004:227). They must be able to understand and respect the needs, motives, career stages and skills of family and non-family employees. The successor must be able to channel the rivalry and conflict between family members in a productive way and gain the support of family and nonfamily employees. Furthermore, the prospective successors must believe in their ability to successfully manage the family business. The successor's capacity to lead, managerial skills and commitment to take over the business are important attributes owners were seeking in successors (Ibrahim, Soufani, Poutziouris \& Lam, 2004:353).

For the purpose of this study, the dependent variable suitability of the younger generation family members was measured by a 5-item scale and refers to whether the younger generation family member is passionate about the family business; has acquired a good knowledge base of the family business; is a businessman to the core; his/her interests and career requirements are suited to the opportunities offered by the family business; and has a good sense of the family business (Venter, 2003; Sharma, 1997).

\section{Independent variables}

The suitability of the younger generation family member or prospective successor to successfully manage the family business after management succession includes, among others, the following aspects, namely. the perceived valueadding to the business by the younger generation family members after they joined the family business; the willingness of the younger generation to be in the business and to take the mantle over in the future; the credibility of the younger generation family member; and whether the younger generation actively empowered themselves to develop and grow as leaders in the family business.

\section{Value-adding by the younger generation}

The younger generation family members should have add significant value to the family business after they joined the business. They should therefore earned their entry into the family business, meaning, in practice, that they contributed more to the business in relation to what they cost the business in salary and benefits (Van der Merwe, 1998). Venter and Boshoff (2007:55) pointed out for management succession to be perceived as successful, the successor should have increased the revenues or profits of the family business after the leadership of the business was handed over to him or her. The successor, furthermore, should have the ability to ensure the sustainability and financial security of the family business after succession (Venter \& Boshoff, 2007:45). That emphasised the fact that the younger generation family member should have the ability to add significant value to the family business after their entry into the business.
For the purpose of this study, the latent variable valueadding by the younger generation was measured by a fouritem scale, i.e. the younger generation family member adds more value to the business than what he/she costs the family business; the business expanded significantly after the younger generation family member's entry into the family business; the younger generation family member's entry into the business did not put financial pressure on the family business; and the business explored new income streams after the younger generation family member's entry into the family business (Venter \& Boshoff, 2007:55; Venter, 2003; Sharma, 1997).

\section{Willingness of the younger generation}

Although it is important for the senior generation to be willing to hand over the family business to the successor (Sharma, Chua \& Chrisman, 2000:236; Matthews, Moore \& Fialko, 1999:163), so too must the younger generation or prospected successor display an interest and willingness to want to manage the family business (Berenbeim, 1990:69). The lack of interest on the part of the successor to take over the business is a commonly cited reason for a problematic succession because a reluctant successor will not be fully committed and may not cooperate in the leadership transition. The presence of a willing and motivated successor to take over the business could influence the quality of a successful succession significantly (Ibrahim \& Ellis, 2004:306; Sharma, Chrisman, Pablo \& Chua, 2001:2425).

The entry of the younger generation into the family business should be voluntary and a personal choice for them. The younger generation or prospected processor should not feel pressured or compelled to enter the family business (Aronoff \& Ward, 1992a:11; Leach \& Bogod, 1999:199). Without freedom to choose, the prospected successor is less likely to make a strong commitment to the family business (Aronoff \& Ward, 1992a:11). Unfortunately, too frequently the offspring of senior generation owner-managers enter the business to please their parents, or because they feel that they do not have a choice. The end result of this can be a next generation that runs the business with half a heart or dies a slow emotional death because they never had a chance to follow their own dreams (Voeller et al., 2002:48).

The willingness of the younger generation or prospective successor to manage the family business may also be influenced by how well the successor's career interests and other personal needs are aligned with opportunities in the business, whether the opportunity exits to exercise influence in the business and the possible rewards from the business (Venter, Boshoff \& Maas, 2003:6).

For the purpose of this study, the willingness of the younger generation was measured by a six-item scale and refers to whether the younger generation family member is happy to be working in the family business; whether the career requirements and interests of the younger generation family member are suited to the opportunities within the family business; whether the younger generation family member finds it exciting to work in the family business; whether the younger generation family member prefers to work in the 
family business (although he/she has other career options available); whether the family business offers the younger generation family member good job security; and whether the younger generation family member has a choice to work in the family business or not (Venter, 2003; Venter et al., 2003:3; Sharma, 1997; Aronoff \& Ward, 1992a).

\section{Credibility of the younger generation}

It is important that the senior generation retiring ownermanager trusts the management skills and competencies of the prospected successor (Sharma, 1997:233). In this study credibility by the younger generation thus means that the senior generation owner-manager trusts the ability of the younger generation to successfully manage the family business in their absence, and ultimately, after the management of the business was transferred to them. A lack of trust in the capabilities of the younger generation can lead to resistance by the senior generation owner-manager to let go (Ibrahim \& Ellis, 2004:283). The credibility or standing of the younger generation or prospected successor in the family business is very important to ensure a successful management succession (Rivers, 2005:117).

For the purpose of this study, the latent variable credibility of the younger generation was measured by a 4-item scale, i.e. the family business functions well when senior generation family members are away for long periods of time; the senior generation family members have faith in the ability of the younger generation family member to run the family business independently; the younger generation family member has, over time, acquired credibility in the family business; and the senior generation family members can count on the younger generation family member to complete tasks successfully (Venter \& Boshoff, 2007:55; Venter, 2003; Sharma, 1997).

\section{Self-empowerment by the younger generation}

The preparation of the younger generation family members to successfully manage the family business after management succession includes aspects such as the active encouragement of the prospective successor to develop himor herself and to be receptive for learning (Matthews et al., 1999:164; Aronoff \& Ward, 1992a:16).

Rawls (1999:292) emphasised that the person being developed must be actively involved in shaping the learning process. The younger generation should understand that they are ultimately responsible for their own development. Self-empowerment is thus key to prepare them to successfully manage the business after succession. They should seize opportunities to develop themselves and should, for instance, attend courses and seminars to better equip him/her for the family business (Venter et al., 2003:17). They should take the lead to develop themselves, be eager to learn and be receptive.

For the purpose of this study, the latent variable selfempowerment by the younger generation, was measured by a five-item scale and refers to whether the younger generation family member attends courses and seminars to better equip him/her for the family business; whether the younger generation family member seizes opportunities to develop his/her skills; whether the younger generation family member is eager to learn and is receptive; whether the younger generation family member is actively busy to qualify himself/herself; and whether the younger generation family member avails him/herself of opportunities to grow and develop (Venter et al., 2003:17; Venter, 2003; Matthews et al., 1999:164; Sharma, 1997).

\section{Research methodology}

\section{Development of the measuring instrument}

In order to operationalise the variables, a measuring instrument was constructed. In this study, the measuring instrument consisted of variables and items whose reliability and validity have been confirmed in previous studies (Venter, 2003; Sharma, 1997; File \& Prince, 1996). Where publicised items were not available, self-developed items were used. For the purpose of this study, four latent variables were identified to measure the dependent variable, perceived suitability of the younger generation (Suit). These are: i.e. value-adding by the younger generation (Value), willingness of the younger generation (Will), credibility of the younger generation (Credit) and self-empowerment by the younger generation (Self). A comprehensive measuring instrument was developed to measure the latent variables (refer to Van der Merwe et al., 2009). The measuring instrument (used in this study) assessed the five latent variables with 24 statements on the basis of a seven-point Likert-type scale ranging from Strongly Disagree (1) to Strongly Agree (7).

\section{The study population}

The target population of this study was small and mediumsized family businesses in South Africa. Numerous attempts were made to secure a database of family businesses in South Africa, but to no avail. Therefore, it was decided to use a convenience sample, by means of the snowball sampling technique, to identify the family businesses that participated in this study. A list of 185 family businesses willing to participate in the study was compiled as a result of these efforts.

The sampling technique and methodology are consistent with that of other family business researchers who have been constrained by the lack of a national database on family businesses (Eybers, 2010; Farrington, 2009; Van der Merwe \& Ellis, 2007; Adendorff, 2004; Sonfield \& Lussier, 2004; Venter, 2003).

\section{Data collection}

Family businesses listed on the database were subsequently contacted to identify the individual family members in the particular family based on the family tree. Questionnaires were then mailed to these family members. Each questionnaire was sent with a covering letter that guaranteed the confidentiality of the responses, as well as a return-paid envelope in order to make it as easy as possible for respondents to take part in the research. A total of 270 usable questionnaires were returned from 77 family 
businesses, which were subjected to further statistical analysis.

\section{Statistical analysis}

The data collected were statistically analysed, using STATISTICA (Statsoft, 2008) and SPSS (SPSS, 2008). Construct validity of the measuring instrument was assessed by means of an exploratory factor analysis and by calculating Cronbach alpha coefficients.

The relationship between the dependent variables and the independent variables was examined by means of multiple regression analysis. The following null hypotheses $\left(\mathrm{H}^{0}\right)$ were formulated in this regard:

$\mathrm{H}^{0 \mathrm{a}}$ : There is no relationship between the dependent variable perceived suitability of the younger generation and the independent variable valueadding by the younger generation.

$\mathrm{H}^{0 \mathrm{~b}}$ : There is no relationship between the dependent variable perceived suitability of the younger generation and the independent variable willingness of the younger generation.

$\mathrm{H}^{0 \mathrm{c}}$ : There is no relationship between the dependent variable perceived suitability of the younger generation and the independent variable credibility of the younger generation.

$\mathrm{H}^{\text {Od }}$ : There is no relationship between the dependent variable perceived suitability of the younger generation and the independent variable degree of self-empowerment of the younger generation.

Thereafter, the association between the demographic variables family employee gender and generation, and the dependent and independent variables was explored by means of paired t-tests. In this regard, the following null hypotheses $\left(\mathrm{H}^{0}\right)$ were formulated:

$\mathrm{H}^{0 \mathrm{e}}$ : There is no difference between the mean scores of gender (male and female) and the variable valueadding by the younger generation in the participating family businesses.

$\mathrm{H}^{0 \mathrm{ff}}$ : There is no difference between the mean scores of gender (male and female) and the variable perceived suitability of the younger generation in the participating family businesses.

$\mathrm{H}^{0 \mathrm{~g}}$ : There is no difference between the mean scores of gender (male and female) and the variable willingness of the younger generation in the participating family businesses.

$\mathrm{H}^{0 \mathrm{~h}}$ : There is no difference between the mean scores of gender (male and female) and the variable credibility of the younger generation in the participating family businesses.

$\mathrm{H}^{0 \mathrm{i}}$ : There is no difference between the mean scores of gender (male and female) and the variable degree of self-empowerment of the younger generation in the participating family businesses.

$\mathrm{H}^{0 \mathrm{j}}$ : There is no difference between the mean scores of family generation (senior and younger) and the variable value-adding by the younger generation in the participating family businesses.

$\mathrm{H}^{0 \mathrm{k}}$ : There is no difference between the mean scores of family generation (senior and younger) and the variable perceived suitability of the younger generation in the participating family businesses.

$\mathrm{H}^{01}$ : There is no difference between the mean scores of family generation (senior and younger) and the variable willingness of the younger generation in the participating family businesses.

$\mathrm{H}^{0 \mathrm{~m}}$ : There is no difference between the mean scores of family generation (senior and younger) and the variable credibility of the younger generation in the participating family businesses.

$\mathrm{H}^{0 \mathrm{n}}$ : There is no difference between the mean scores of family generation (senior and younger) and the variable degree of self-empowerment of the younger generation in the participating family businesses.

The association between business size and the variables was explored by means of independent t-tests. The following null hypotheses $\left(\mathrm{H}^{0}\right)$ were formulated:

$\mathrm{H}^{0 \mathrm{o}}$ : There is no difference between the mean scores of business size (small and medium) and the variable value-adding by the younger generation in the participating family businesses.

$\mathrm{H}^{0 \mathrm{p}}$ : There is no difference between the mean scores of business size (small and medium) and the variable perceived suitability of the younger generation in the participating family businesses.

$\mathrm{H}^{0 \mathrm{q}}$ : There is no difference between the mean scores of business size (small and medium) and the variable willingness of the younger generation in the participating family businesses.

$\mathrm{H}^{0 \mathrm{r}}$ : There is no difference between the mean scores of business size (small and medium) and the variable credibility of the younger generation in the participating family businesses.

$\mathrm{H}^{0 \mathrm{~s}}$ : There is no difference between the mean scores of business size (small and medium) and the variable degree of self-empowerment of the younger generation in the participating family businesses.

All these associations were examined on a family level (SPSS, 2008). 


\section{Results and discussion}

\section{Demographic information}

The demographic information of the participating family members and businesses is presented in Table 1 .

Table 1: Demographic information of the sample

\begin{tabular}{|c|c|c|}
\hline Variable & Frequency & Percentage $(\%)$ \\
\hline \multicolumn{3}{|l|}{ Gender $(\mathbf{n}=270)$} \\
\hline Male & 174 & 64,44 \\
\hline Female & 96 & 35,56 \\
\hline \multicolumn{3}{|l|}{ Generation $(n=270)$} \\
\hline $\begin{array}{l}\text { In-laws (younger } \\
\text { generation) }\end{array}$ & 24 & 8,89 \\
\hline $\begin{array}{l}\text { Senior generation } \\
\text { (parents) }\end{array}$ & 123 & 45,56 \\
\hline $\begin{array}{l}\text { Younger generation } \\
\text { (offspring) }\end{array}$ & 119 & 44,07 \\
\hline $\begin{array}{l}\text { Other (e.g. uncles, aunts, } \\
\text { cousins) }\end{array}$ & 4 & 1,48 \\
\hline \multicolumn{3}{|c|}{ Age category (years) $(n=270)$} \\
\hline Younger than 29 & 56 & 20,74 \\
\hline $30-39$ & 69 & 25,56 \\
\hline $40-49$ & 32 & 11,85 \\
\hline $50-59$ & 65 & 24,07 \\
\hline Older than 60 & 48 & 17,78 \\
\hline \multicolumn{3}{|c|}{ Business size (permanent employees) $(n=77)$} \\
\hline $\begin{array}{l}1-10 \text { (micro \& very } \\
\text { small) }\end{array}$ & 13 & 16,88 \\
\hline 11-50 (small business) & 46 & 59,74 \\
\hline $\begin{array}{l}51-200 \text { (medium } \\
\text { business) }\end{array}$ & 18 & 23,38 \\
\hline
\end{tabular}

The majority of the 270 participating respondents in this study were under the age of 40 years $(46,30 \%), 11,85 \%$ between the ages of 40 and 49 , with $41,85 \%$ over the age of 50 years. Approximately two-thirds of the respondents were male $(64,44 \%)$. A total of $45,56 \%$ of the respondents were senior generation family employees (parents), with $44,07 \%$ representing the younger generation family employees (offspring). The rest of the family employees $(10,37 \%)$ represented in-laws (married to younger generation family members) and other family employees such as uncles, aunts or cousins.

A total of $16,88 \%$ of the 77 family businesses who participated in this study can be categorised as micro- and very small businesses in the South African context (10 employees and less) and 59,74\% small businesses (between 11 and 50 permanent employees). The rest $(23,38 \%)$ can be categorised as medium-sized businesses (between 51 and 200 employees).

\section{Construct validity of the measuring instrument}

To assess the discriminant validity of the 25 items measuring the dependent and independent variables in this study, an exploratory factor analysis was conducted using the computer programme SPSS (SPSS, 2008).
In this study, there was theoretical justification to believe that the factors measuring management succession planning would correlate with each other, therefore an Oblimin oblique rotation was performed on the principal components of the exploratory factor analysis, as suggested by Field (2009:643). The correlation matrix for these five variables indicates correlations of 0,214 to 0,414 between the variable combinations (Ellis \& Steyn, 2003:53), confirming that an oblique rotation should have been used (Field, 2009:643).

Kaiser's criterion was used to determine the number of factors to be extracted, namely to retain factors with eigenvalues greater than one (Field, 2009:647). A total of 24 of the 25 items demonstrated sufficient discriminant validity by loading to a sufficient extent and, therefore, only one item was deleted. The pattern matrix of the remaining 24 items is provided in Table 2. Factor loadings greater than 0,35 were considered significant, as recommended by Field (2009:644).

Five factors with eigen-values greater than one, explaining $65,53 \%$ of the variance before rotation, were extracted in the exploratory factor analysis. After rotation, these factors could be identified as the theoretical dimensions of valueadding by the younger generation, perceived suitability of the younger generation, willingness of the younger generation, credibility of the younger generation and degree of self-empowerment by the younger generation. When factors are correlated, sums of squares of loadings cannot be added to obtain a percentage variance explained for each of the rotated factors as in the case of uncorrelated factors (SPSS, 2008). The Kaiser-Meyer-Olkin measure of sampling adequacy of 0,929 indicates that patterns of correlations are compact and that factor analysis should yield reliable factors (Field, 2009:647). Bartlett's test of sphericity yielded a $p$-value of smaller than 0,0001 , indicating that correlation between variables is sufficient for factor analysis.

After rotation, four of the items loaded onto more than one factor (values greater than 0,35 ). The item, Credit4, loaded significantly on both the factors, namely value-adding by the younger generation and credibility of the younger generation. The item, Will4, loaded on both the factors, namely value-adding by the younger generation and perceived suitability of the younger generation. The item, Self4, furthermore, loaded on both the factors, namely value-adding by the younger generation and degree of selfempowerment of the younger generation. Rather than deleting the above-mentioned items, it was decided to classify them under the factor that yielded the highest factor loading. The classification of the items under the factors value-adding by the younger generation (Credit4), perceived suitability of the younger generation (Will4), and degree of self-empowerment of the younger generation (Self4) respectively also have the highest interpretation value and, furthermore, makes sense in practice. 
Table 2: Pattern matrix of Oblimin rotated-principal component factor analysis ${ }^{(1)}$

\begin{tabular}{|c|c|c|c|c|c|}
\hline Item $^{(2)}$ & $\begin{array}{c}\text { Factor 1: }^{(3)} \\
\text { Value-adding }\end{array}$ & $\begin{array}{l}\text { Factor 2: } \\
\text { Suitability }\end{array}$ & $\begin{array}{c}\text { Factor 3: } \\
\text { Willingness }\end{array}$ & $\begin{array}{c}\text { Facto 4: } \\
\text { Credibility }\end{array}$ & $\begin{array}{c}\text { Factor 5: } \\
\text { Self-empowerment }\end{array}$ \\
\hline Value2 & 0,665 & $-0,018$ & 0,079 & 0,042 & 0,206 \\
\hline Value3 & 0,565 & $-0,296$ & 0,010 & 0,129 & 0,119 \\
\hline Suit2 & 0,563 & $-0,327$ & 0,033 & 0,034 & 0,095 \\
\hline Credit4 & 0,489 & $-0,152$ & 0,213 & 0,356 & $-0,112$ \\
\hline Suit1 & 0,168 & $-0,837$ & 0,031 & $-0,135$ & 0,021 \\
\hline Suit3 & 0,295 & $-0,710$ & $-0,091$ & 0,019 & $-0,028$ \\
\hline Will3 & $-0,103$ & $-0,701$ & 0,306 & 0,052 & $-0,003$ \\
\hline Will4 & $-0,382$ & $-0,595$ & 0,141 & 0,320 & 0,015 \\
\hline Suit5 & 0,259 & $-0,565$ & 0,230 & 0,135 & $-0,120$ \\
\hline Will2 & 0,006 & $-0,450$ & 0,190 & 0,098 & 0,317 \\
\hline Value1 & 0,034 & $-0,427$ & $-0,102$ & 0,303 & 0,322 \\
\hline Suit4 & $-0,076$ & $-0,401$ & 0,295 & 0,149 & 0,306 \\
\hline Self1 & 0,142 & $-0,357$ & 0,147 & 0,332 & 0,120 \\
\hline Will6 & $-0,001$ & $-0,042$ & 0,771 & $-0,054$ & $-0,040$ \\
\hline Will1 & $-0,256$ & $-0,274$ & 0,691 & $-0,026$ & 0,054 \\
\hline Will5 & 0,068 & 0,215 & 0,665 & 0,078 & 0,300 \\
\hline Value5 & 0,367 & 0,063 & 0,565 & 0,107 & 0,048 \\
\hline Credit2 & 0,220 & $-0,188$ & $\mathbf{0 , 5 0 5}$ & 0,146 & 0,031 \\
\hline Value4 & $-0,151$ & 0,030 & $-0,112$ & 0,836 & 0,161 \\
\hline Credit1 & 0,267 & 0,051 & 0,144 & 0,740 & $-0,239$ \\
\hline Credit3 & 0,303 & $-0,071$ & 0,222 & 0,418 & 0,161 \\
\hline Self1 & $-0,025$ & 0,134 & 0,091 & 0,006 & 0,824 \\
\hline Self2 & 0,256 & $-0,242$ & 0,097 & $-0,032$ & 0,606 \\
\hline Self4 & 0,386 & $-0,086$ & $-0,002$ & 0,120 & 0,488 \\
\hline Cronbach Ipha & $\mathbf{0 , 8 2 2}$ & 0,906 & 0,766 & 0,687 & 0,724 \\
\hline
\end{tabular}

1. Loadings greater than 0,35 were considered significant

2. The items included in the factor analysis are provided in Appendix 1

3. The five extracted factors were labelled as follows:

Factor 1: Value-adding by the younger generation (value-adding)

Factor 2: Perceived suitability of the younger generation (suitability)

Factor 3: Willingness of the younger generation (willingness)

Factor 4: Credibility of the younger generation (credibility)

Factor 5: Degree of self-empowerment by the younger generation (self-empowerment)

The item, Value5, loaded on both the factors, namely valueadding by the younger generation and willingness of the younger generation. The classification of Value5 under the factor that yielded the highest factor loading, does, however, not make sense in practice and it was decided to classify it under the factor value-adding by the younger generation.

Factor one, labelled value-adding by the younger generation, comprised five items. Three of the five items used to measure the latent variable value-adding by the younger generation (refer to Table 1: Value2, Value3 and Value5) loaded significantly onto factor one as expected. One item, Suit2 related to perceived suitability of the younger generation and one item, Credit4, used to measure the latent variable credibility of the younger generation, was also included into factor one, being regarded by respondents as being related to value-adding by the younger generation.

The second factor, labelled perceived suitability of the younger generation, comprised nine items. Four of the five items that were used to measure the latent variable, perceived suitability of the younger generation (Table 2: Suit1, Suit3, Suit4 and Suit5), loaded onto factor two as expected. Three willingness of the younger generation items (Table 2: Will2, Will3 and Will4) also loaded onto factor two. One value-adding by the younger generation (Value1) and one self-empowerment of the younger generation (Self3) item also loaded onto factor two. The respondents thus regarded these items as additional measures of the variable perceived suitability of the younger generation.

With regard to the third factor, labelled willingness of the younger generation, three of the items that were used to measure the latent variable, willingness of the younger generation, loaded onto this factor. One credibility of the younger generation item (Credit2) also loaded onto factor three and was thus regarded by respondents as an additional willingness of the younger generation measure.

Two of the four items (Table 2: Credit1 and Credit3) used to measure the latent variable credibility of the younger generation, loaded onto factor four, also labelled credibility of the younger generation. One value-adding by the younger generation item (Value4), also loaded onto factor four, being regarded by respondents as related to credibility of the younger generation.

Three of the five items used to measure the latent variable self-empowerment by the younger generation (Table 2: items Self1, Self2, Self4) loaded onto factor five, as expected. Factor 5 was labelled degree of self-empowerment of the younger generation. 
From the factor loadings it is clear that all five latent variables used to measure the role of the younger generation family members (refer to Appendix 1), were incorporated into the five factors (Table 2). The wording of the statements (items) measuring the five latent variables is provided in Appendix 1.

The exploratory factor analysis, together with the interpretability of the factors, provides some evidence of construct validity.

\section{Reliability of the measuring instrument}

In order to assess the internal consistency between the items of the measuring instrument, Cronbach alpha coefficients were calculated (Page \& Meyer, 2000:292). The Cronbach alpha coefficient is based on the average correlation of variables within a construct (SAS Institute, 2005:295). The greater the Cronbach alpha coefficient is, the more reliable the scale. Nunnally and Bernstein (1994:265) suggest that for acceptable reliability the Cronbach alpha coefficient should be greater than 0,7 .

All 270 participants' responses were used to determine the reliability of the extracted factors (refer to Table 2). Only one factor, credibility of the younger generation $(0,687)$, yielded a Cronbach Alpha value below the customary cutoff value of 0,70 suggested for internal consistency (Nunnally \& Bernstein, 1994:265). Field (2009:678), however, indicated that a Cronbach alpa value as low as 0,60 can be acceptable when people's attitudes are measured. The results thus indicate that the instrument used in this study to measure the perceived suitability of the younger generation to successfully manage the family businesses after management succession, has acceptable reliability.

\section{Relationship between the constructs}

In order to determine whether the independent variables value-adding by the younger generation, willingness by the younger generation, credibility of the younger generation and degree of self-empowerment by the younger generation have an influence on the dependent variable perceived suitability of the younger generation, a multiple regression analysis was performed. Factor scores for each participant were computed as the average of all items contributing to the relevant factor, automatically replacing missing values by mean substitution.

The scores of family members belonging to a specific family can be considered to be dependent on that family's situation. As independence of data is one of the assumptions of linear regression, the average counts for each of the 77 families were taken as data points in a multiple regression analysis. The results of the multiple regression analysis for the influence of the independent variables on the dependent variable are presented in Table 3. A normal probability plot on the residuals of this fit confirmed the assumption of normality.
Table 3: Multiple regression results: Impact of valueadding, willingness, credibility and degree of selfempowerment of the younger generation on the perceived suitability of the younger generation

\begin{tabular}{l|c|c|c|c|c}
\hline \multirow{2}{*}{ Model } & \multicolumn{2}{|c|}{$\begin{array}{c}\text { Non-standardised } \\
\text { coefficients }\end{array}$} & $\begin{array}{c}\text { Standardised } \\
\text { coefficients }\end{array}$ & \multirow{2}{*}{ t-value } & p-level \\
\cline { 2 - 5 } & $\mathbf{B}$ & $\begin{array}{c}\text { Std. } \\
\text { Error }\end{array}$ & Beta & & \\
\hline Constant & 0,663 & 0,254 & & 2,608 & $0,010^{* *}$ \\
\hline Value-adding & 0,330 & 0,058 & 0,331 & 5,698 & $0,000^{* *}$ \\
\hline Willingness & 0,286 & 0,046 & 0,319 & 6,195 & $0,000^{* *}$ \\
\hline Credibility & 0,209 & 0,055 & 0,196 & 3,772 & $0,000^{* *}$ \\
\hline $\begin{array}{l}\text { Self- } \\
\text { empowerment }\end{array}$ & 0,064 & 0,040 & 0,080 & 1,598 & 0,111 \\
\hline \multicolumn{2}{|l}{$\mathrm{R}^{2}=0,613(* * \mathrm{p}<0,05)$} & & & & \\
\hline
\end{tabular}

Table 3 indicates that, in practice, a significant percentage $(61,3 \%)$ of the variation in the perceived suitability of the younger generation in the participating family businesses is explained by the value-adding by the younger generation, willingness of the younger generation, credibility of the younger generation and self-empowerment by the younger generation.

The null hypotheses that there is no relationship between the dependent variable perceived suitability of the younger generation and the independent variables value adding by the younger generation $\left(\mathrm{H}^{0 \mathrm{a}}\right)$, willingness of the younger generation $\left(\mathrm{H}^{0 \mathrm{~b}}\right)$ and credibility of the younger generation $\left(\mathrm{H}^{0 \mathrm{c}}\right)$ respectively, were rejected. The positive regression coefficients indicate that the suitability of the younger generation in the study population is related to the valueadding of the younger generation, the willingness of the younger generation to be in the family business and the credibility of the younger generation.

No significant relationship could, however, be found between the perceived suitability and degree of selfempowerment of the younger generation. The null hypothesis that there is no relationship between the perceived suitability of the younger generation and the degree of self-empowerment of the younger generation $\left(\mathrm{H}^{\text {od }}\right)$ was thus accepted.

\section{Comparing the mean differences between constructs for demographic variables}

The differences in the means between the demographic variables gender (male and female) and generation (senior and younger) of the participating family employees for the variables were examined by paired t-tests, because the responses of members of the same family can be considered to be dependent. The difference between the means of small and medium-sized businesses (business size) regarding the variables will, however, be examined by independent $t$-tests. The analysis was performed on a family level, where the average scores for each of the 77 families were taken as data points.

Table 4 shows the relationships between the variables and the demographical variables gender, generation and business size respectively, with the mean $(\bar{x})$, standard deviation $(s)$ and t-test ( $p$-value). 
Table 4: The results of the differences in means between the variables for different demographic variables

\begin{tabular}{|c|c|c|c|c|c|c|c|}
\hline \multicolumn{8}{|c|}{ Gender } \\
\hline \multirow[t]{2}{*}{ Variable } & \multicolumn{3}{|c|}{ Male } & \multicolumn{3}{|c|}{ Female } & Comparison \\
\hline & $n$ & $\bar{x}$ & $s$ & $n$ & $\bar{x}$ & $s$ & $p$ \\
\hline Value-adding & 52 & 5,70 & 0,76 & 52 & 5,65 & 1,00 & 0,682 \\
\hline Perceived suitability & 52 & 5,72 & 0,71 & 52 & 5,60 & 0,84 & 0,270 \\
\hline Willingness & 52 & 5,69 & 0,72 & 52 & 5,50 & 0,99 & 0,104 \\
\hline Credibility & 52 & 5,76 & 0,72 & 52 & 5,66 & 0,79 & 0,338 \\
\hline Self-empowerment & 52 & 5,41 & 0,98 & 52 & 5,22 & 1,09 & 0,205 \\
\hline \multicolumn{8}{|c|}{ Generation } \\
\hline \multirow[t]{2}{*}{ Variable } & \multicolumn{3}{|c|}{ Senior } & \multicolumn{3}{|c|}{ Younger } & Comparison \\
\hline & $N$ & $\bar{x}$ & $s$ & $n$ & $\bar{x}$ & $s$ & $p$ \\
\hline Value-adding & 75 & 5,71 & 0,94 & 75 & 5,61 & 0,86 & 0,284 \\
\hline Perceived suitability & 75 & 5,68 & 0,90 & 75 & 5,63 & 0,86 & 0,650 \\
\hline Willingness & 75 & 5,80 & 0,82 & 75 & 5,34 & 1,08 & $<0,001$ \\
\hline Credibility & 75 & 5,89 & 0,79 & 75 & 5,65 & 0,86 & 0,019 \\
\hline Self-empowerment & 75 & 5,56 & 1,02 & 75 & 5,17 & 1,07 & 0,008 \\
\hline \multicolumn{8}{|c|}{ Business size } \\
\hline \multirow[t]{2}{*}{ Variable } & \multicolumn{3}{|c|}{ Small } & \multicolumn{3}{|c|}{ Medium } & Comparison \\
\hline & $n$ & $\bar{x}$ & $s$ & $n$ & $\bar{x}$ & $s$ & $p$ \\
\hline Value-adding & 59 & 5,63 & 0,76 & 18 & 5,83 & 0,81 & 0,338 \\
\hline Perceived suitability & 59 & 5,62 & 0,73 & 18 & 5,89 & 0,69 & 0,175 \\
\hline Willingness & 59 & 5,52 & 0,81 & 18 & 5,87 & 0,71 & 0,104 \\
\hline Credibility & 59 & 5,71 & 0,65 & 18 & 5,93 & 0,74 & 0,228 \\
\hline Self-empowerment & 59 & 5,30 & 0,87 & 18 & 5,54 & 0,87 & 0,281 \\
\hline
\end{tabular}

The results indicated no statistically significant difference ( $p$ $<0,05)$ in the mean values between the perceptions of male and females with regard to all variables. The null hypothesis that there is no difference between the mean scores of the demographic variable gender (male and female) is thus accepted in the case of all the variables, i.e. value-adding by the younger generation $\left(\mathrm{H}^{0 \mathrm{e}}\right)$, perceived suitability of the younger generation $\left(\mathrm{H}^{\mathrm{Of}}\right)$, willingness of the younger generation $\left(\mathrm{H}^{0 \mathrm{~g}}\right)$, credibility of the younger generation $\left(\mathrm{H}^{0 \mathrm{~h}}\right)$ and degree of self-empowerment by the younger generation $\left(\mathrm{H}^{0 \mathrm{i}}\right)$. This means that there were no differences in the ratings between male and females with regard to all five variables measuring the perceived suitability of the younger generation.

Furthermore, statistically significant differences in the mean values between the senior and younger generation family employees with regard to the variables willingness of the younger generation $(p<0,001))$, credibility of the younger generation $(p=0,019)$ and degree of self-empowerment by the younger generation $(p=0,008)$ were calculated. The null hypothesis that there is no difference between the mean scores of the demographic variable family generation (senior and younger) is thus rejected in the case of the variables willingness of the younger generation $\left(\mathrm{H}^{01}\right)$, credibility of the younger generation $\left(\mathrm{H}^{0 \mathrm{~m}}\right)$ and degree of selfempowerment by the younger generation $\left(\mathrm{H}^{0 \mathrm{n}}\right)$ and accepted in the case of the variables value-adding by the younger generation $\left(\mathrm{H}^{0 \mathrm{j}}\right)$ and perceived suitability of the younger generation $\left(\mathrm{H}^{0 \mathrm{k}}\right)$. This means that the senior generation family members perceived the willingness of the younger generation, the credibility of the younger generation and self-empowerment by the younger generation more positive than the younger generation family members. The reason for these statistically significant differences might be because senior generation family managers, and in this case still the owner-managers, feel more in control of the business and therefore overrate these variables. The younger generation, on the other hand, often feel excluded from the business or are more negative towards these variables in the family business.

Although the family members employed by medium-sized family businesses rated all the variables more positive than family members employed by small family businesses, these differences were not statistically significant. The null hypothesis that there is no difference between the mean scores of the demographic variable business size (small and medium) is thus accepted in the case of all the variables, i.e. value-adding by the younger generation $\left(\mathrm{H}^{0 \mathrm{o}}\right)$, perceived suitability of the younger generation $\left(\mathrm{H}^{0 \mathrm{p}}\right)$, willingness of the younger generation $\left(\mathrm{H}^{0 \mathrm{q}}\right)$, credibility of the younger generation $\left(\mathrm{H}^{0 \mathrm{r}}\right)$ and degree of self-empowerment by the younger generation $\left(\mathrm{H}^{0 \mathrm{~s}}\right)$.

\section{Limitations and suggestions for further research}

The study attempted to make a contribution to the body of knowledge on the determinants of the perceived suitability of the younger generation to successfully manage the business after management succession in small to mediumsized family businesses. This study, however, only assessed some of the determinants and can be regarded as an exploratory study. More comprehensive research is still needed to clarify all the underlying dimensions of management succession in family businesses to enhance our understanding of these issues.

Although family businesses from all provinces in South Africa took part in this study, due to the convenience sampling technique, this cannot be considered to be representative of all small and medium-sized family 
businesses in South Africa. Care should therefore be exercised in the interpretation and utilisation of the results, and the findings of the study cannot be generalised. In other words, the typical family business could be underrepresented in the sample.

In this study the exploratory factor analysis provides some evidence of construct validity, but further research is needed before the measuring scale can be utilised to diagnose these issues in small and medium-sized family businesses. It is recommended that more advanced statistical procedures for scale validation, such as structural equation modelling, should be utilised in the further development of the measuring instrument. Supplementary research on the use of the measuring scale is also necessary to refine its norms.

\section{Management implications and practical recommendations}

Management succession involves the planning, selection and preparation of the next generation family members and the transfer of management to them. This is a process that takes place over a long period of time and should, therefore, be communicated effectively within the family and to other stakeholders.

This study confirms a strong positive relationship between the perceived suitability of the younger generation to successfully manage the business after succession, and the perceived value-adding, willingness and credibility of the younger generation family members. This means in practice that the senior generation ownermanager will be willing to transfer the business to the younger generation if they have the perception that the younger generation have the ability to add significant value to the business, if the younger generation are eager and willing to take over the management of the business in the future, and if the owner-manager trusts their ability to successfully manage the business on their own. Successful management succession is thus dependent on both generations (parents and children) willingness to successfully transfer the family business from the senior to the younger generation family members.

It is recommended that family businesses utilise a diagnostic instrument such as the measuring questionnaire used in this study to assess the suitability of the younger generation as well as the willingness of the senior generation to let go (refer to Van der Merwe, 2010a).

A competent and willing successor is important for successful succession. The development of the younger generation should be tailored for the specific individual and should be based on a formal leadership and management development plan. It is, however, important that the younger generation family members are willing to take over the business in the future and that they work hard to develop themselves and to gain the trust and respect of the senior generation retiring owner-managers by hard work, discipline and a sense of responsibility.

A combination of the following aspects could ensure in practice a well-balanced and competent successor, i.e. formal level of education and training, entry-level position, years of work experience inside and outside the business, extensive use of external networks, managerial capabilities, knowledge of business operations and human relations with the retiring owner-manager, the family and key stakeholders inside and outside the family business.

Management succession is an emotional issue that could create serious conflict in the family business. Family businesses should, therefore, start to plan for management succession at an early stage just after the younger generation entered the family business. It is important to address the issue of succession before it becomes personal and emotional and can therefore be addressed more comfortably and more rationally. It is recommended that family businesses establish a task team to plan for management succession. This team could include the senior generation owner-managers (parents), the prospective successor, other key family members, directors and non-family managers. Such a task team could be appointed during a family forum meeting to obtain a mandate from the entire family. The process should be planned meticulously and the issue of management succession should receive urgent attention.

\section{Conclusions}

This study confirms the important role that the younger generation family members play in the successful transfer of the management of the family business to the next generation family members. Successful management succession can ensure the continuity and longevity of the family business (Venter \& Boshoff, 2007; File \& Prince, 1996).

This study reports some evidence of construct validity and reliability of a questionnaire to measure the perceived suitability of the younger generation to successfully manage the business after succession in small and medium-sized family businesses in South Africa. Five factors describing the theoretical dimensions of value-adding by the younger generation, perceived suitability of the younger generation (dependent variable), willingness by the younger generation, credibility of the younger generation and degree of selfempowerment by the younger generation (see Table 2), were extracted. It is recommended that more advanced statistical procedures for scale validation, such as structural equation modelling, be utilised in further development of the measuring scale.

The positive regression coefficients indicate that the suitability of the younger generation in the study population is related to the value-adding of the younger generation, the willingness of the younger generation to be in the family business and the credibility of the younger generation. In other words, the more value-adding by the younger generation, the more the younger generation is willing to be in the family business, or the more the credibility of the younger generation, respectively, the higher the perceived suitability of the younger generation to successfully manage the family business after management succession. The findings of this study, thus, confirm the findings of other scholars (Rivers, 2005:17; Ibrahim \& Ellis, 2004:227; Sharma et al., 2001:24-25; among others). 
No significant relationship could, however, be found between the perceived suitability of the younger generation and the degree of self-empowerment of the younger generation. This finding contradicts the notion of Rawls (1999:292) who emphasised the importance of the selfempowerment by the younger generation to improve their suitability to successfully manage the family business after management succession.

The findings of this study indicated that the senior generation family managers are significantly more positive regarding the willingness of the younger generation to manage the family business, the credibility of the younger generation and the degree of self-empowerment by the younger generation. No literature could, however, be found to explain or contradict these findings. The reason for these statistically significant differences might be because senior generation family managers, and in this case still the ownermanagers, feel more in control in the business and therefore overrate these variables. The younger generation, on the other hand, often feels excluded from the business or is more negative towards these variables in the family business. The results of this study confirm the findings of other studies that report significant differences in the view of senior and younger generation family members with regard to other management succession constructs (Van der Merwe, 2010b; Van der Merwe et al., 2009:11, 12).

The lower rating by the younger generation regarding their willingness to be in the family business is, however, a concern. The good rating of the credibility of the younger generation by the senior generation is definitely a positive sign and indicates trust in the capabilities of the younger generation. But what is significant, is that younger generation family members rated their self-empowerment efforts lower than the senior generation. It is suggested that more research is still needed to more clearly understand these differences and to evaluate the impact of that on successful management succession.

No significant differences could, however, be found between the ratings of male and females, as well as between family members involved in medium-sized or small family businesses with regard to any of the variables. These findings confirm the findings of previous studies that could also not find significant differences between the perceptions of male and female family members concerning management succession (Van der Merwe et al., 2009:11, 12).

\section{References}

Adendorff, C.M. 2004. 'The development of a cultural family business model of good corporate governance for Greek family businesses in South Africa'. Unpublished doctoral thesis, Rhodes University, Grahamstown.

Afghan, N. \& Wiqar, T. 2007. Succession in family businesses of Pakistan: Kinship culture and Islamic inheritance law. Centre for Management and Economic research: Lahore University of Management Sciences. Working paper 07/54:1-27.
Aronoff, C.E. \& Ward, J.L. 1992a. Another kind of hero: Preparing successors for leadership. Marietta, GA: Business Owner Resources.

Aronoff, C.E. \& Ward, J.L. 1992b. Family business succession: The final test of greatness. Marietta. GA: Business Owner Resources.

Astrachan, J.H. \& Shanker, M.C. 2003. 'Family businesses' contribution to the U.S. economy: A closer look', Family Business Review, 16(3):211-219.

Balshaw, T. 2003. Thrive: Making family business work. Cape Town: Human \& Rousseau.

Basu, A. 2004. 'Entrepreneurial aspirations among family business owners: An analysis of ethnic business owners in the UK', International Journal of Entrepreneurial Behaviour \& Research, 10(1/2):12-33.

Berenbeim, R.E. 1990. 'How business families manage the transition from owner to professional management', Family Business Review, 3(1):69-110.

Berent, M.M., Flören, R.H., Uhlaner, L.M. \& Appelman, H. 2009. 'Family businesses in the Netherlands: Characteristics and success factors'. Policy paper presented at the $9^{\text {th }}$ Annual IFERA World Family Business Conference, Cyprus, 24-27 June.

Brenes, E.R., Madrigal, K. \& Molina-Navorro, G.E. 2006. 'Family business structure and succession: Critical topics in Latin American experience', Journal of Business Research, 59(3):372-374.

Craig, J.B. \& Moores, K. 2009. 'Championing family business issues to influence public policy: Evidence from Australia'. Policy paper presented at the $9^{\text {th }}$ Annual IFERA World Family Business Conference, Cyprus, 24-27 June.

Daba, N.K. 2007. 'Management succession in black-owned family businesses in Limpopo province'. Unpublished MBA dissertation, North-West University, Potchefstroom, South Africa.

De Massis, A., Chua, J. \& Chrisman, J.J. 2008. 'Factors preventing intra-family succession', Family Business Review, 21(2):183-199.

Dyer, W.G. Jr. 1986. Cultural change in family firms: anticipating and managing business and family traditions. San Francisco, CA: Jossey-Bass.

Ellis, S.M. \& Steyn, H.S. 2003. 'Practical significance (effect sizes) versus or in combination with statistical significance (p-values)', Management Dynamics, 12(4):5153.

Eybers, C. 2010. 'Copreneurs in South African small and medium-sized businesses'. Unpublished M.Com.dissertation, Nelson Mandela Metropolitan University, Port Elizabeth. 
Farrington, S. 2009. 'Sibling partnerships in South African small and medium-sized family businesses'. Unpublished doctoral thesis, Nelson Mandela Metropolitan University, Port Elizabeth.

Field, A. 2009. Discovering statistics using SPSS. $3^{\text {rd }}$ Edition. London: Sage.

File, K.M. \& Prince, R.A. 1996. 'Attributions for family business failure', Family Business Review, 9(2):171-184.

Hess, E.D. 2006. The successful family business: A proactive plan for managing the family and the business. Westport: Praeger.

Ibrahim, A.B. \& Ellis, W.H. 2004. Family business management: Concepts and practice. $2^{\text {nd }}$ Edition. Dubuque, IA: Kendall/Hunt.

Ibrahim, A.B., Soufani, K., Poutziouris, P. \& Lam, J. 2004. 'Qualities of an effective successor: The role of education and training', Education and Training, 46:474-480.

Leach, P. \& Bogod, T. 1999. Guide to family businesses. $3^{\text {rd }}$ Edition. London: Kogan Page.

Le Breton-Miller, I., Miller, D. \& Steier, L.P. 2003. 'Towards an integrative model of effective FOB succession', Entrepreneurship Theory and Practice, 28(4):305-328.

Maas, G., Van der Merwe, S.P. \& Venter, E. 2005. Family businesses in South Africa: A practical governance guide. Stellenberg: Content Solutions.

Matthews, C.H., Moore, T.W. \& Fialko, A.S. 1999. 'Succession in the family firm: A cognitive categorization perspective', Family Business Review, 12(2):159-169.

Morck, R. \& Yeung, B. 2004. 'Family control and the rent seeking society', Entrepreneurship Theory and Practice, 28(4):391-409.

National Small Business Act see South Africa.

National Small Business Amendment Act see South Africa.

Netsianda, A. 2008. 'Management succession in blackowned family businesses: An exploratory study'. Unpublished MBA dissertation, North-West University, Potchefstroom, South Africa.

Nunnally, J. \& Bernstein, I.H. 1994. Psychometric theory. $3^{\text {rd }}$ Edition. New York, NY: McGraw-Hill.

Page, C. \& Meyer, D. 2000. Applied research design for business and management. Roseville: McGraw-Hill.

Phan, P.H., Butler, J.E. \& Lee, S. 2005. 'Corporate governance and management succession in family businesses'. Paper presented at First Haneil Foundation Entrepreneurship and Management Conference, Berlin, German.
Rawls, L.H. 1999. Seeking succession: How to continue the family business legacy. Maitland, FL: Horizon Business Press.

Rivers, D.W. 2005. Prescriptions for a healthy family business. Raleigh, NC: The Family Firm Institute.

SAS Institute Inc. 2005. SAS Institute Inc., SAS OnlineDoc®, Version 9.1, Cary, NC: SAS Institute.

Schuman, A.M. 2004. Nurturing the talent to nurture the legacy: Career development in the family business. Marietta, GA: Family Enterprise Publishers.

Sharma, P. 1997. 'Determinants of the satisfaction of the primary stakeholders with the succession process in family firms'. Unpublished doctoral thesis, University of Calgary, Canada.

Sharma, P., Chrisman, J.J., Pablo, A.L. \& Chua, J.H. 2001. 'Determinants of initial satisfaction with the succession process in family firms: A conceptual model', Entrepreneurship Theory and Practice, 33(6):17-29.

Sharma, P., Chua, J.H. \& Chrisman, J.J. 2000. 'Perceptions about the extent of succession planning in Canadian family firms', Canadian Journal of Administrative Sciences, 17(3):233-244.

Sonfield, M.C. \& Lussier, R.N. 2004. 'First-second and third-generation family firms: A comparison', Family Business Review, 17(3):189-202.

South Africa. 1996. 'National Small Business Act (Act 102 of 1996)', Government Gazette, 377(17612).

South Africa. 2004. 'National Small Business Amendment Act (Act 29 of 2004)', Government Gazette, 474(27101).

SPSS Inc. 2008 SPSS® 16.0 for Windows, Release 16.0.0, Copyright $@$ by SPSS Inc., Chicago, IL: SPSS.

Statsoft, Inc. 2008. STATISTICA (Data Analysis Software System). Vers. 7.1. [online] URL: www.statsoft.com.

Swart, P.J. 2005.'Unique challenges facing family businesses'. Unpublished MBA dissertation, North-West University, Potchefstroom, South Africa.

Van der Merwe, S.P. 1998. 'Formal planning in family businesses in the Vaal Triangle'. Unpublished doctoral thesis, North-West University, Potchefstroom, South Africa.

Van der Merwe, S.P. 2010a. 'The determinants of the readiness of senior generation owner-managers to let go in small and medium-sized family businesses', South African Journal of Economics and Management Sciences (in press.)

Van der Merwe, S.P. 2010b. 'An assessment of the determinants of successor development in family businesses', Acta Commercii (in press.) 
Van der Merwe, S.P. \& Ellis, S.M. 2007. 'An exploratory study of some of the determinants of harmonious family relationships in small and medium-sized family businesses', Management Dynamics, 16(4):24-35.

Van der Merwe, S.P., Venter, E. \& Ellis, S.M. 2009. 'An exploratory study of some of the determinants of management succession planning in family businesses', Management Dynamics, 18(4):2-17.

Venter, E. 2003. 'The succession process in small and medium-sized family businesses in South Africa.' Unpublished doctoral thesis, University of Port Elizabeth, Port Elizabeth, South Africa.

Venter, E. \& Boshoff, C. 2005. 'The influence of successorrelated factors on the succession process in small and medium-sized businesses', Family Business Review, 18(4):283-303.

Venter, E. \& Boshoff, C. 2007. 'The influence of organisation-related factors on the succession process in small and medium-sized family businesses', Management Dynamics, 16(1):42-55.

Venter, E., Boshoff, C. \& Maas, G. 2003. 'The influence of organisational factors on successful succession in family businesses', Management Dynamics, 12(4):2-17.

Voeller, M., Fairburn, L. \& Thompson, W. 2002. Exit right: A guided tour of succession planning for families-inbusiness-together. $2^{\text {nd }}$ Edition. Toronto: Summit Run. 
Appendix 1: Items measuring the latent variables

\begin{tabular}{|c|c|}
\hline Item & Statement \\
\hline \multicolumn{2}{|r|}{ SUITABILITY OF THE YOUNGER GENERATION } \\
\hline Suit1 & The younger generation family member is passionate about the family business \\
\hline Suit2 & The younger generation family member has acquired a good knowledge base of the family business \\
\hline Suit3 & The younger generation family member is a businessman to the core \\
\hline Suit4 & $\begin{array}{l}\text { The younger generation family member's interests and career requirements are suited to the opportunities offered } \\
\text { by the family business }\end{array}$ \\
\hline Suit5 & The younger generation family member has a good sense of the family business \\
\hline \multicolumn{2}{|r|}{ VALUE-ADDING BY THE YOUNGER GENERATION } \\
\hline Value1 & The younger generation family member adds more value to the business than what he/she costs the family business \\
\hline Value2 & The business expanded significantly after the younger generation family member's entry into the family business \\
\hline Value3 & The younger generation family member adds significant value to the family business \\
\hline Value4 & $\begin{array}{l}\text { The younger generation family member's entry into the business did not put financial pressure on the family } \\
\text { business }\end{array}$ \\
\hline Value5 & $\begin{array}{l}\text { The business explored new income streams after the younger generation family member's entry into the family } \\
\text { business }\end{array}$ \\
\hline \multicolumn{2}{|r|}{ WILLINGNESS OF THE YOUNGER GENERATION } \\
\hline Will1 & The younger generation family member is very happy to be working in the family business \\
\hline Will2 & $\begin{array}{l}\text { The career requirements and interests of the younger generation family member are suited to the opportunities } \\
\text { within the family business }\end{array}$ \\
\hline Will3 & The younger generation family member finds it exciting to work in the family business \\
\hline Will4 & $\begin{array}{l}\text { The younger generation family member prefers to work in the family business (although he/she has other career } \\
\text { options available) }\end{array}$ \\
\hline Will5 & The family business offers the younger generation family member good job security \\
\hline Will6 & The younger generation family member has a choice to work in the family business or not \\
\hline \multicolumn{2}{|r|}{ CREDIBILITY OF THE YOUNGER GENERATION } \\
\hline Cred1 & The family business functions well when senior generation family members are away for long periods of time \\
\hline Cred2 & $\begin{array}{l}\text { The senior generation family members have faith in the ability of the younger generation family member to run the } \\
\text { family business independently }\end{array}$ \\
\hline Cred3 & The younger generation family member has, over time, acquired credibility in the family business \\
\hline Cred4 & $\begin{array}{l}\text { The senior generation family members can count on the younger generation family member to complete tasks } \\
\text { successfully }\end{array}$ \\
\hline \multicolumn{2}{|r|}{ SELF-EMPOWERMENT BY THE YOUNGER GENERATION } \\
\hline Self1 & $\begin{array}{l}\text { The younger generation family member attends courses and seminars to better equip him/her for the family } \\
\text { business }\end{array}$ \\
\hline Self2 & The younger generation family member seizes opportunities to develop his/her skills \\
\hline Self3 & The younger generation family member is eager to learn and is receptive \\
\hline Self4 & The younger generation family member is actively busy to qualify himself/herself \\
\hline Self5 & The younger generation family member avails himself of opportunities to grow and develop \\
\hline
\end{tabular}

